DOI: https://doi.org/10.32839/2304-5809/2021-9-97-30

уДК 646.7

Улибіна Л.Ю., Гарбуз М.В.

Харківський науково-дослідний експертно-криміналістичний центр Міністерства внутрішніх справ України

\title{
ОСОБЛИВОСТІ КЛАСИФІКАЦІЇ ДЕКОРАТИВНОЇ КОСМЕТИКИ ДЛЯ ГУБ ПРИ ПРОВЕДЕННІ СУДОВОЇ ТОВАРОЗНАВЧОЇ ЕКСПЕРТИЗИ
}

\begin{abstract}
Анотація. В Україні стан декоративної косметики для губ за останні роки на ринку спостерігає тенденцію з розширення асортименту, а також його модернізащію та осучаснення, тому необхідно зробити розгляд комплексного визначення класифікації, представленого на сьогодні у товарознавстві. Дивлячись на це були розглянуті особливості класифікації сучасної декоративної косметики для губ, а також вимоги до їх матеріалів та сировини, маркування символами, пакування та подальше зберігання, нормативнотехнічна документація та ї̈ вимоги щодо показників номенклатури якості виробів та їх застосування на декоративній косметиці для губ. Проведено аналіз асортименту сучасної декоративної косметики для губ, яка з'явився на ринку за останні десять років. Досліджено вплив споживчих властивостей щодо асортиментного формування на ринку. Було висунуто пропозищію, щодо включення різновидів сучасної декоративної косметики для губ до загальної класифікації, щоб надалі судові експерти могли використовувати ці дані при проведенні судової товарознавчої експертизі.
\end{abstract}

Ключові слова: товарознавство, сучасна декоративна косметика для губ, класифікація сучасної декоративної косметики для губ, асортимент сучасної декоративної косметики для губ, судова товарознавча експертиза.

Ulybina Lionella, Harbuz Mariia

Kharkov Scientific and Research, Experimental and Forensic Center of the Internal Affairs Ministry of Ukraine

\section{FEATURES OF CLASSIFICATION DECORATIVE COSMETICS FOR LIPS WHEN CARRYING OUT SHIP PRODUCT EXPERTISE}

Summary. In Ukraine, the state of make-up for the lips in recent years on the market shows a tendency to expand the range, as well as its modernization and modernization, so it is necessary to consider a comprehensive definition of the classification presented today in commodity science. Looking at this, the peculiarities of classification of modern make-up for lip cosmetics, as well as requirements for their materials and raw materials, marking with symbols, packaging and further storage, regulatory and technical documentation and its requirements for nomenclature of product quality and their use on make-up. An analysis of the range of modern lip cosmetics that have appeared on the market over the past ten years. The influence of consumer properties on assortment formation on the market is investigated. A proposal was made to include varieties of modern make-up for the lips in the general classification, so that in the future forensic experts can use this data in conducting forensic examination. In forensic practice today, the issues of determining the market value of stolen property are relevant, so that in the future the victim can calculate the material damage. Decorative lip cosmetics also become stolen property. The question of the peculiarities of the modern classification of make-up for lips in commodity science is quite relevant, especially when determining the properties of these groups of goods and depending on the general characteristics. Modern decorative cosmetics for the lips belong to the goods that have a complex range, which is quite large in terms of production methods and its composition, and also includes a wide variety of species and varieties. The situation on the market of decorative lip cosmetics in Ukraine in recent years has seen such trends as increasing the range, its modernization and modernization, so it is necessary to comprehensively consider the definition of classification presented in commodity science today.

Keywords: commodity science, modern make-up for lips, classification of modern make-up for lips, range of modern make-up for lips, forensic examination.

$\Pi^{\circ}$ остановка проблеми. У судово-експертній практиці на сьогоднішній день є актуальними питання щодо визначення ринкової вартості майна, що вкрали, щоб надалі можна було потерпілому розрахувати матеріальні збитки. Майном, що викрадають стає й декоративна косметика для губ. Питання особливості сучасної класифікації декоративної косметики для губ у товарознавстві є досить актуальним, особливо під час визначення властивостей даних груп товарів та в залежності від загальної характеристики. Сучасна декоративна косметика для губ належить до товарів, що має складний асортимент, який досить великий за способами виробництва та своїм складом, а також включає у себе дуже різноманітні види та різновиди.
Ситуація на ринку декоративної косметики для губ в Україні останніми роками спостерігає такі тенденції, як збільшення асортименту, iï осучаснення та модернізацію, тому необхідно комплексно розглянути визначення класифікації, представлене у товарознавстві на сьогоднішній день.

Аналіз останніх досліджень і публікацій. Ряд авторів вже сповіщала у своїх роботах питання асортименту та класифікації декоративної косметики для губ, також матеріалів з яких виробляється косметика, особливості, вимоги та характеристика до них, адаптування чинного нормативного забезпечення для подальшого використовування цих даних при проведенні судової товарознавчої експертизі, а також проблеми їх вдосконалення: 
Кулюкіна Ю.В., Абдуллазянова Г.Г., Галяметдинов Ю.Г., Булганина С.В., Лабазова А.В., Белоусова К.В., Иванова Д.С. та інші [1-4].

Виділення невирішених раніше частин загальної проблеми. На осучасненому ринку з'явилася велика кількість декоративної косметики для губ, вона має додаткові фрункції та нове призначення, тому виникає потреба для повторного розглядання й удосконалення вже існуючих класифрікащій й асортименту.

Мета статті. Головна мета ціеї роботи - надання товарознавчих характеристик декоративній косметиці для губ на сучасному ринку. Дослідження сфрормованих споживчих властивостей сучасної декоративної косметики для губ, розгляд класифікації та асортименту, ознайомлення 3 вимогами нормативно-технічної документації з приводу контролю якості декоративної косметики для губ, а також при маркуванні, пакуванні та зберіганні.

Виклад основного матеріалу. Косметика та парфумерія відносяться до особливої групи непродовольчих товарів без яких, у наш час, складно представити усучаснене та повноцінне людське життя. На споживчому ринку України обсяги продажу косметичних та парфумованих засобів, на сьогодні, посідають четверте місце. Ці речі входять до предметів повсякденного користування та мають величезний попит на ринку товарів [5, с. 6].

Існує два типи косметики: за допомогою одного відтворюють догляд за шкірою та волоссям, за допомогою другого ("декоративна косметика») підкреслюють індивідуальність красоти і увиразнюють губи та очі, що приховує дефекти зовнішності та поліпшують форму обличчя [6, с. 238].

Виготовляються така декоративна косметика в залежності від призначення:

1) Для губ:

- бальзами;

- блиски;

- помади.

2) Для брів, очей та губ:

- олівці.

3) Для обличчя:

- рум'яна;

- пудра;

- блиск;

- олівці маскувальні;

- грим.

4) Для повік:

- тіні.

5) Для вій:

- туш.

6) інші вироби [7, с. 2].

Декоративна косметика, що використовуеться для губ включає до переліку:

- губну помаду;

- блиск та бальзам для губ;

- контурний пензлик [8, с. 114].

Серед декоративної косметики для губ найпоширенішою $е$ помада. У промисловості випускають губні помади тональні та без кольору.

Основними вимогами до губних помад $є$ такі:

- безпечність продукту;

- зовнішній вигляд відповідний еталонному;

- гладке нанесення на губи;

- якісне утримання на губах [9, с. 256-257].
Склад і дію губної помади наближено до жирових кремів. Які мають такий склад:

- жирова основа;

- наповнювач;

- барвник;

- розчинник для барвника;

- розчинник для стружки.

Сам склад губної помади відповідає компонентам (кількість яких може коливатися від 15 до 30):

- високоякісний жир;

- масло ароматизоване;

- віск;

- продукти нафрти (парафін, церезин);

- корисні добавки (вітаміни групи А, E, F, лецитин, екстракт алое та інші) [9, с. 257].

До складу помад для губ спеціального призначення входять:

- сонцезахисні (захищають від ультрафріолетового спектра променів, що викликае висихання і розтріскування губ);

- інші, що мають у своєму складі протизапальні, біологічно активні та плівкоутворювальні речовини [9, с. 257].

Класифрікація помади для губ:

I. За призначенням:

- гігієнічна помада - за доглядом здоров'я шкіри;

- декоративна помада - для приховування недоліків.

II. За кольором: від 1 до 99 тонів (від лілового до блідо-рожевого). Кожен виробник має свою нумерацію, тому у продаж може надходити помада різного тону під одним номером.

III. За блиском:

- перламутрові;

- матові;

- має блиск.

IV. За стійкістю забарвлення буває:

- просто;

- важко змивною.

Прості тримаються не так довго у порівнянні iз важко змивних.

V. За ступенем жирності:

- cyxi;

- напівжирні;

- жирні.

VI. За фрормою споживчої тари футляри у вигляді олівців мають такі форми:

- круглу;

- овальну;

- прямокутну [9, с. 258].

Футляри виробляють з таких матеріалів:

- метал

- пластмаса;

- дерево.

VII. За консистенцією:

- рідка;

- тверда [9, с. 258].

Асортимент помад для губ оновлюеться на постійній основі та з'являються помади 3 новими властивостями.

1) Помади «Хамелеон» мають властивості змінювати колір залежно від $\mathrm{pH}$ середи шкіри людини:

- блакитний колір змінюеться на відтінки від світло-рожевого до малинового;

- зелений колір дає забарвлення від рожевого до червоного кольору;

- помаранчевий колір змінюеться на відтінки від абрикосового до коралового. 
2) Помади, що мають додатковий ефект:

- зволожувальний;

- світлозахисний;

- водостійкий [9, с. 259].

Маркують помаду губ за таким принципом, вказуючи:

1) термін придатності;

2) перелік інгредієнтів;

3) ароматичну композицію у складі не зазначають, а відображають як один інгредієнт у вигляді таких написів: ароматизатор, парфумерна або ароматична композиція, також запашка.

Пакують губні помади дотримуючись таких умов:

1) фрасують $у$ :

- баночки, пенали: металеві, полімерні, скляні та комбіновані;

- картонні коробочки;

- оправи дерев'яні [7, с. 5].

Також є дозвіл на використання інших видів споживчої тари при погодженні із споживачем.

2) споживча тара має забезпечити максимальну безпечність для виробів під час транспортування, зберігання та подальшого використовування. Товар не повинен випадати із споживчої тари.

3) споживча тара має бути заповнена не менш ніж до країв, але також відповідати масі та об'єму, а також щільно закрита кришками.

4) якщо є потреба до комплекту додають допоміжні засоби: аплікатори, щіточки тощо.

5) за масою допустимі від'ємні відхили становлять не більше $6 \%$.

6) споживча та пакувальна тари повинно бути виготовлено 3 матеріалів, що дозволені при контакті з харчовими продуктами та парфумованокосметичними засобами [7, с. 5].

Для того щоб перевірити чи відповідають помади для губ вимогам стандарту проводять такі випробування: періодичні та приймально-здавальні.

Приймально-здавальні оцінюють завдяки таким ознакам:

- органолептичні: зовнішній вигляд, запах та колір, покривна здатність;

- фрізико-хімічні показники: кислотне число, показник $\mathrm{pH}$ у воді, температура крапле падіння (окрім рідких товарів);

- маркування та пакування.

Мінімум один раз у квартал виконують випробовування за фрізико-хімічними та мікробіологічними показниками [7, с. 5-6].

Блиск або бальзам для губ, має як і помади мають склад із багатьох ком-понентів:

- природний віск;

- жирові складові;

- різні пардумовані олії;

- блискоутворюючі речовини;

- плівкоутворюючі речовини;

- барвник;

- корисні добавки [9, с. 264].

За кольором випускають біля 11 тонів. Блиск має властивості освіжати губи та захищати від атмосорерних опадів.

Форма випуску:

- баночка

- олівці (у пеналах) [9, с. 264].

Косметичні бальзами виготовляють такої консистенщії:

- кремоподібні;

- гелеподібні;
- легко рухливої маслянистої рідини [10, с. 2].

Маркують блиски та бальзами для губ за певним принципом, вказуеться:

1) маса нетто у таких одиницях, як грам, а об'ем - у мілілітрах або сантиметрах в кубі;

2) мінімальний термін придатності;

3) список інгредієнтів, який можна нанести у будь-якому порядку після основних [10, с. 5].

Пакують блиски та бальзами для губ дотримуючись таких умов:

1) споживчу тару заповнюють відповідно технічним вимогам на бальзами конкретних назв враховуючі дані про масу чи об'єм.

2) Якщо блиск у тарі 50 г включно, його допустимі від'ємні відхили - 6 \% від номінальної маси;

Якщо блиск у тарі від 50 г до 100 г включно, його допустимі від'ємні відхили - 4,5 г від номінальної маси;

Якщо блиск у тарі від 100 г до 200 г включно, його допустимі від'емні відхили - 4,5 \% від номінальної маси [10, с. 5].

Для перевірки відповідності косметичних бальзамів до вимог стандарту проводять приймальноздавальні та періодичні випробовування.

Приймально-здавальні оцінюють за такими ознаками:

- органолептичні: зовнішній вигляд, запах та колір, покривна здатність;

- фрізико-хімічні показники: кислотне число (рідкі бальзами), показник рН у воді, термостабільність та колоїдна (кремоподібні та гелеподібні бальзами);

- маркування та пакування.

Мінімум один раз у квартал виконують випробовування за показником $\mathrm{pH}$ у воді та летких речовин, а також за мікробіологічними показниками $[10$, с. 5$]$.

Контурний олівець призначений для того, щоб можна було відкоригувати обрису губ, за кольором випускають не маленьку кількість тонів.

Склад олівців подібний до помад, але має більш суху та тверду консистенцію через вміст соскоподібних речовин.

Для того, щоб олівець був «стійкий», до його складу вводять силікони. Силікони у свою чергу випаровуються дуже швидко та дають можливість кольоровим пігментам фріксуватися на шкірі.

Основа для грифеля - каолін, а віск надає грифелю стійкості.

Незважаючи на максимальну стійкість, олівець повинен бути достатньо м'яким, щоб не пошкодити шкіру губ та навколо, також не повинен бути дуже жирним, щоб контур намальований олівцем для губ не розтікався. За тоном він має відповідати тону губної помади [8, с. 264-265].

Маркують та пакують олівці для губ по тому ж самому принципу, що і помаду для губ. Виробник гарантуе відповідність олівців для губ вимогам транспортування та зберігання.

Термін придатності визначає підприемствовиробник узгоджуючи 3 центральним органом виконавчої влади у сфері охорони здоров'я України [7, с. 9].

Висновки 3 даного дослідження i перспективи. У підсумку, слід звернути увагу, що наведена у статті інорормація про декоративну косметику для губ, щодо їі пакування, маркування, зберігання та вимог до якості, може бути ви- 
користана судовими експертами при проведенні судової товарознавчої експертизи.

Абсолютно різні підходи до класифікації декоративної косметики для губ, наявні на сьогодні, не можуть бути використані для проведення товарознавчих експертиз у повному обсязі, через:

1) відсутність систематизованого повного переліку ознак класифікації (як у навчальних підручниках та іншій літературі, так і в класифрікаціях, наведених у нормативно-технічних документах);

2) відсутність оновлених даних у класифікаційних системах щодо технологій виробництва та обробки матеріалів декоративної косметики для губ в щілому.

Всі ці фрактори призводять до величезних витрат часу при проведенні асортиментної іденти- фікації декоративної косметики для губ, адже потребуе пошуку ознак класифікацій у різних класифікаційних системах, їх аналізу та узагальнення для практичного застосування.

Також необхідним стає доповнення таких класифікацій, при подальшій роботі, за умови оновлення асортименту. Дивлячись на усі фракти виникає необхідність у побудові сучасної класифокації декоративної косметики для губ, призначеної для проведення ідентифрікації та товарознавчої експертизи.

Отже, вищезазначене має об'єктивну передумову для перегляду й удосконалення наявних класифрікацій із урахуванням змін асортименту сучасної декоративної косметики для губ.

\section{Список літератури:}

1. Кулюкіна Ю.В. Особливості українського парфумерно-косметичному ринку. Практичний маркетинг. 2007. Вип. 7(125). С. 14-16.

2. Абдуллазянова Г.Г. Вплив рецептурного складу на властивості губної помади лікувально-профілактичного призначення Вісник технологічного університету. 2017. Т. 20. Вип. 3. С. 149-152.

3. Абдуллазянова Г.Г., Галяметдинов Ю.Г. Вплив рецептурного складу на органолептичні і фрізико-хімічні властивості губної помади. Вісник технологічного університету. 2015. Т. 18. Вип. 16. С. 204-206.

4. Булганіна С.В., Лабазова А.В., Білоусова К.В., Іванова Д.С. Дослідження вибору декоративної косметики. Наука Краснояр'я. 2019. Т. 8. Вип. 2-3. С. 7-11.

5. Яцяк О.М. Парфумерно-косметичні товари : навч.-метод. посібник. Коломия, 2019. 222 с.

6. Вилкова С.А. Товарознавство та експертиза непродовольчих товарів : словник-довідник. 2-е вид. Москва : Видавнича торгова корпорація «Дашков і Кํ», 2015. 264 с.

7. ДСТУ 4774:2007. Вироби косметичні для макіяжу на жировосковій основі Держспоживстандарт України. Київ, 2009. 15 с.

8. Головко М.П., Пенкіна Н.М., Колесник В.В. Товарознавство та експертиза в митній справі. Харків : ХДУХТ, 2015. 152 c.

9. Пешук Л.В., Бавіка Л.І., Демідов І.М. Технологія парфумерно-косметичних продуктів : навч. видання. Київ : Центр учбової літератури, 2007. 376 с.

10. ДСТУ 4763:2007. Бальзами косметичні. Держспоживстандарт України. Київ, 2008. 13 с.

\section{References:}

1. Kuliukina Y.V. (2007) Osoblyvosti ukrainskoho parfumerno-kosmetychnomu rynku [Features of the Ukrainian perfume and cosmetics market]. Praktychnyi marketynh, vol. 7(125), pp. 14-16.

2. Abdullazianova H.H. (2017) Vplyv retsepturnoho skladu na vlastyvosti hubnoi pomady likuvalno-profilaktychnoho pryznachennia [Influence of prescription composition on the properties of lipstick for therapeutic and prophylactic purposes]. Visnyk tekhnolohichnoho universytetu, vol. 3, pp. 149-152.

3. Abdullazianova H.H., Haliametdynov Y.H. (2015) Vplyv retsepturnoho skladu na orhanoleptychni i fizykokhimichni vlastyvosti hubnoi pomady [Influence of prescription composition on organoleptic and physicochemical properties of lipstick]. Visnyk tekhnolohichnoho universytetu, vol. 6, pp. 204-206.

4. Bulhanina S.V., Labazova A.V., Bilousova K.V., Ivanova D.S. (2019) Doslidzhennia vyboru dekoratyvnoi kosmetyky [Research of the choice of decorative cosmetics]. Nauka Krasnoiaria, vol. 2-3, pp. 7-11.

5. Jacek O.M. (2019) Parfumerno-kosmetychni tovary [Perfumery and cosmetics]. Kolomyia. (in Ukrainian)

6. Vilkova S.A. (2015) Tovaroznavstvo ta ekspertyza neprodovolchykh tovariv [Commodity science and examination of non-food products]. Moscow. (in Russian)

7. DSTU 4774:2007 (2009) Vyroby kosmetychni dlia makiiazhu na zhyrovoskovii osnovi [Cosmetic products for makeup on a fat-wax basis]. Kyiv: Derzhspozhyvstandart Ukrainy.

8. Golovko M.P., Penkina N.M., Kolesnik V.V. (2015) Tekhnolohiia parfumerno-kosmetychnykh produktiv [Commodity science and expertise in customs]. Kharkiv: KhDUHT. (in Ukrainiane)

9. Peshuk L.V., Bavika L.I., Demidov I.M. (2007) Tovaroznavstvo ta ekspertyza $v$ mytnii spravi [Technology of perfumery and cosmetics]. Kyiv. (in Ukrainian)

10. DSTU 4763:2007 (2008) Balzamy kosmetychni [Cosmetic balms]. Kyiv: Derzhspozhyvstandart Ukrainy. 